\title{
Olumsuz Elektronik Ağızdan Ağıza Pazarlama İletişimine Etki Eden Faktörlerin Belirlenmesi: Z kuşağı Örneklemi ${ }^{1}$
}

\section{Determining the Factors That Affect Negative Electronic Word of Mouth Marketing Communication: Sample of Generation $\mathrm{Z}$}

\author{
Hazal BİZTATAR, Türkiye, hazalbiztatar@gmail.com \\ Orcid No: 0000-0002-6730-2391 \\ Eda YAŞA ÖZELTÜRKAY, Çă̆ Üniversitesi, Türkiye, edayasa@cag.edu.tr \\ Orcid No: 0000-0001-9248-1371 \\ Deniz YALÇINTAŞ, Çağ Üniversitesi, Türkiye, denizyalcintas@ cag.edu.tr \\ Orcid No: 0000-0001-6436-7221
}

\begin{abstract}
Öz: Çalışmada Z kuşağı (1995 yılı ve sonrası doğan) tüketicilerinin olumsuz elektronik ă̆ızdan ağıza pazarlama iletişimlerine etki eden faktörlerin ortaya çıkarılması amaçlanmıştır. Bu amaç doğrultusunda, 318 Z kuşağı tüketicisi ile yüzyüze anket formları aracılığılyla toplanan veriler SPSS 20 istatistik paket programı ile analiz edilmiştir. Ölçeklerin geçerlilik (faktör analizi) ve güvenirlik (Cronbach Alfa) analizlerinden sonra çoklu dogrusal regresyon analizleri aracılı̆̆lyla hipotez testleri yapılmıştır. Yapılan faktör analizi sonucu olumsuz elektronik ăğzdan ağıza pazarlama iletişimine etki eden dört boyut; "teknolojik beceri ve sosyal medya", "aile ve akran etkisi", "elektronik ağızdan ağıza pazarlama deneyimi" ve "elektronik posta iletişimi” olarak adlandırılmıştır. Literatüre dayalı olarak adlandırllan bu dört boyutun olumsuz elektronik ă̆ızdan ağıza pazarlama üzerindeki etkisini belirlemek için yapılan regresyon analizinin sonucuna göre; tüketicilerin olumsuz elektronik ăğzdan ağıza pazarlama iletişiminlerinde aile bireyleri ve akranların etkisi hariç, diğer üç boyutun etkili olduğu ortaya çıkmıştır.
\end{abstract}

Anahtar Sözcükler: Olumsuz Deneyim, Elektronik Ağızdan Ă̆ıza Pazarlama, Sosyal Medya, Z kuşă̆l

Abstract:The study's aim is to reveal the factors that affect negative electronic word of mouth marketing communications of $Z$ generation consumers (born in 1995 and later). For this purpose, data collected through face to face questionnaires with $318 \mathrm{Z}$ generation consumers were analyzed with SPSS 20 Statistical Package Program. After the validity (factor analysis) and reliability (Cronbach's Alpha) analyzes of the scales, hypothesis tests were performed by means of multiple linear regression analyzes. As a result of factor analysis, four dimensions that negatively affect electronic word of mouth marketing communication; "technological skills and social media", "family and peer influence", "electronic word of mouth marketing experience" and "e-mail communication". According to the results of the regression analysis conducted to determine the effect of these four dimensions, which are based on literature, on negative electronic word of mouth marketing; it was found that three other dimensions were effective in the negative electronic word of mouth marketing communication of consumers except the family members and peers.

Keywords: Negative Experience, Electronic Word of Mouth Marketing, Social Media, Generation Z

\section{Giriş}

Pazarlamaya ve pazarlama iletişiminin tarihsel gelişim sürecine bakıldığında, pazarlama iletişimi çabalarının her geçen gün daha fazla önem kazandığı görülmektedir. Bu durumun başlıca sebepleri arasında üretimin toplumsal bir nitelik kazanıp büyük boyutlara ulaşması, tüketici sayısının artması ve tüketicilerin daha çok bilinçlenmesi, tüketicilerin istek ve beklentilerinin sürekli değişmesi, üreticiler ile tüketiciler arasındaki mesafenin sürekli artması, küreselleşmeyle beraber rekabetin büyümesi, tüketicilere ürün ve hizmetlerin ulaştırılabilmesinde kullanılan aracı kurumların çoğalması gibi nedenler yer almaktadır (Yurdakul, 2003, 10). Son yıllarda rekabet ortamında işletmelerin tüketicilere ulaşması daha zor bir hale gelmektedir. Çok sayıda işletme, fazla sayıda ürünle sınırlı sayıdaki tüketiciyi kendi müşterisi yapmak için uğraşmaktadır. Bu sebeple pazarda bulunan tüketiciler, çok fazla sayıda pazarlama iletişimi mesajına maruz kalmaktadırlar. İnternet gibi gelişen teknolojiler vasıtasıyla da bu mesajlara tüketicilerin bulunduğu her ortamda denk gelmek mümkündür (Ezzatırad, 2014, 1). Özellikle medyanın biçim değiştirmesi, yeni medya ve sosyal medya ortamı, bilgilerin çeşitlenmesinde, yaygınlaşmasında, bilgiye ulaşılmasında ve bilginin içselleştirilmesinde belirleyici bir etken rolünü üstlenmiştir. Dolayısıyla müşteriler, çeşitli medya ortamlarında görüşlerini kolaylıkla dile getirebilmektedir (Vilpponen vd., 2006; Kamiloğlu ve Yurttaş, 2014). Araştırmalar (Kwon vd., 2011; Nusair vd., 2013; Lee vd., 2013), sosyal medya ve mobil teknolojinin, satın alımlardan önce bilgi alışverişinde çok önemli bir kanal haline geldiğini ve çevrimiçi etkileşimlerin modern müşteri deneyiminin kilit rolü olduğunu göstermiştir. Günümüzde tüketiciler satın

\footnotetext{
${ }^{1} \mathrm{Bu}$ çalışma, Çağ Üniversitesi Sosyal Bilimler Enstitüsü İşletme Yönetimi Ana Bilim Dalı’nda hazırlanan, “Olumsuz Elektronik Ağızdan Ağıza Pazarlama İletişimine Etki Eden Faktörler: Z Kuşağı Tüketicilerinin Görüşlerini Belirlemeye Yönelik Bir Araştırma” başlıklı yüksek lisans tezinden türetilmiş olup, 4-6 Eylül'de Yaşar Üniversitesi'nde düzenlenen II. Business and Organization Conference'da sözlü sunum olarak sunulmuştur.
} 
Biztatar, H,. Yaşa Özeltürkay, E., Yalçıntaş, D. / Journal of Yasar University, 2019, 14 (Special Issue), 115-123

almada ticari kaynaklardan başka kişisel bilgi kaynaklarından da fayda sağlamaktadır. Özellikle aile, arkadaş, eş, dost, komşu gibi kişilerden oluşan bu kaynaklar, ürün ve hizmetlere ilişkin satın alma karar süreçlerinde olumlu veya olumsuz etkiler yaratabilmektedirler (Özkan ve Yıldız, 2015, 360). Psikologlar çocukların davranışlarının, ebeveynlik stillerine ve aile kültürlerine paralel olarak, büyüdükleri ortamla da yakından ilişkili olduğunu belirtmişlerdir (Eckleberry-Hunt ve Tucciarone, 2011; Mitchell vd., 2015). İnternetin ve hızın kuşağı olan Z kuşağ üyeleri ise, tüketimden etkilenen ve tüketim trendlerini etkileyen bir profil oluşturmaktadırlar (Altuntuğ, 2012, 204). Z kuşağı üyeleri doğdukları andan itibaren internet, sosyal medya gibi dijital teknolojilerle ve cep telefonu, bilgisayar, tablet gibi elektronik cihazlarla yakından ilgili olan bir kuşaktır (Sönmez, 2016, 108). Ekonomik, sosyal, kültürel ve teknolojik değişimler sonucunda, Z kuşağı üyeleri tüketim kararları ve davranışlarında yaşlarının çok ilerisinde etkilerde bulunmaktadırlar. Bu yüzden, diğer kuşakların oluşturmuş olduğu pazarlama ve tüketim davranışlarını büyük oranda değiştirip geleceğin tüketici profilini biçimlendirecekleri tahmin edilmektedir (Altuntuğ, 2012, 206).

Konuyla ilgili olarak benzer çalışmalar (Drennan ve McColl-Kennedy, 2003; Mattila ve Mount, 2003; Cheung vd., 2008; Vermeulen ve Seegers, 2009; Boo ve Kim, 2013; Zhang vd., 2015; Toros Dapiapis, 2016; Göktaş ve Tarakçı, 2018; Luo vd., 2018; Philp vd., 2018; Weitzl vd., 2018; Chung ve Lee, 2019) genel olarak ağızdan ağıza pazarlamanın önemine, tüketicilerin tercihlerine olan etkilerine, çevrimiçi platformlarda yer alan olumsuz durum ve yorumların tüketici davranışlarını, tutum ve niyetlerini etkilediklerine dayanmaktadır.

Olumsuz elektronik ağıdan ağıza pazarlama iletişimine etki eden faktörler ile ilgili Z kuşağı tüketicilerinin görüşlerini belirlemeye yönelik gerçekleştirilen bu çalışma iki bölümden oluşmaktadır. Birinci bölümde konuya ilişkin yazın taraması yer alırken, ikinci bölümüde ise çalışmanın metodolojisi ile sonuç ve öneriler yer almaktadır.

\section{Liretatür Taraması}

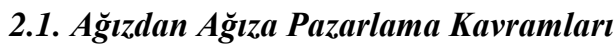

Ağızdan ağıza pazarlama kavramı (AAP), dünya pazarlama stratejilerinde kısa sürede ün kazanan ve pazarlama bölümünde yer alan kişi ve kuruluşların gün geçtikçe daha çok yoğunlaştıkları bir kavram niteliğine sahiptir (Yavuzyılmaz, 2015, 431). Ağızdan ağıza pazarlamanın tüketicilerin davranışları üzerindeki etkisini inceleyen en eski araştırmacılardan biri olan Buttle $(1988,242)$, ağızdan ağıza pazarlamayı ürün, marka veya hizmet üzerinde ticari amaçlardan bağımsız kişiler arası sözel iletişim ile yaratılmış olan algılar olarak karakterize etmiştir. AAP farkındalık, beklentiler, algılar, tutumlar, davranışsal niyetler ve davranışları etkileyen bir unsur olduğu ve ürünü denemek için bir karar vermede reklam vermekten daha önemli olduğu sonucuna varmıştır. Ağızdan ağıza pazarlamada öneride bulunan bir tüketici beklenti içerisinde değildir, bu yüzden o ürün ya da hizmetle alakalı hatalı bilgi vermek gibi bir durum söz konusu olmamaktadır. Bu da ağızdan ağıza pazarlamanın diğer pazarlama türlerinden daha güvenilir olduğunu göstermektedir (Uyar ve Kılıçaslan, 2016, 390). Elektronik ağızdan ağıza pazarlama ise mevcut veya potansiyel tüketiciler arasında internete dayalı yazılı iletişim yolları ile tüketicilerin birbirleriyle etkileşimleri olarak tanımlanmış olup tüketici karar alma sürecinde önemli bir rol oynamaktadır (You vd., 2015, 19). Elektronik ağızdan ağıza pazarlama platformlarının türlerine örnek olarak ürün inceleme web siteleri, perakendecilerin ve markaların web siteleri, sosyal paylaşım siteleri, kişisel bloglar, mesaj panoları vb. verilebilir (Lee ve Youn, 2009: 474).

Tüketiciler, hayal kırıklığına uğradıkları ve beklentilerinin karşılanmadığı ürünlerden daha çok söz edebilmektedir. Amaç, tüketicileri yakın çevreyi satın almada bilinçli hale getirerek yanlış karar verilmesinin önüne geçerek uyarmaktır. Tüketimle ilgili çevrimiçi topluluklar aslında bir ürün kategorisine ilgi duyan bireylerin satın alma önerileri, diğer benzer kişilerle bağlantı kurmak veya şikayet veya iltifat etkileşimlerine katılmak için bilgi alışverişinde bulunduğu AAP ağlarını temsil etmektedir. Bu çevrimiçi topluluklar içinde devam eden AAP iletişimiyle topluluklar hem uzmanlaşmış hem de geniş tabanlı ilişkilerde bilgi ve sosyal destek sağlamakta ve sosyal ve tüketim davranışlarında önemli bir tamamlayıcı haline gelmektedir (Brown vd., 2007, 3). Olumsuz deneyimler ağızdan ağıza pazarlamanın oluşmasındaki en etkili motive şekilleridir. Bu doğrultuda pazarlamacıların dikkat etmesi gereken konu olumsuz ağızdan ağıza pazarlamanın tüketici tutum ve davranışlarında önemli bir etkiye sahip olduğudur (Güven, 2014, 87).

Olumsuz elektronik ağızdan ağıza pazarlama, iyi gerçekleşmemiş bir satın alma sonrası tüketicide oluşan memnuniyetsizlikten kaynaklanan tüketici şikâyet davranışının bir türüdür. İnternet aracıllğıyla coğrafi sınırların kısıtlanması gibi bir durum söz konusu olmadığından, farklı özelliklere sahip birçok kişi tarafından tüketici şikâyetleri hızla yayılmaktadır. Olumsuz elektronik ağızdan ağıza pazarlamanın yaratılmasının, internetin hızlı bir şekilde yayılmasından dolayı dolaşımı pek kontrol edilememekle birlikte önemi gözden kaçırılmamalıdır (Chen, 2015,1). Arndt (1967), çalışmasında ağızdan ağıza pazarlamanın hem olumlu hem de olumsuz etkilere sahip olduğunu, ancak olumsuz ağızdan ağıza pazarlamanın olumlu ağızdan ağıza pazarlamaya oranla daha çok etki alanına sahip olduğunu ortaya koymuştur. Öyle ki Desatnick (1987)'in Beyaz Saray tüketici ilişkilerinden (White House Office of Consumer Affairs) yaptığı alıntı doğrultusunda kötü deneyimlere sahip tüketicilerin \%90'nın yeniden almaya eğilimi olmadığı her tüketicinin en az dokuz ayrı tüketiciye deneyimlerini aktardığı ve bu tüketicilerin \%13'ünün ise 20 'den fazla tüketiciye ulaştığ 1 gözlemlenmiştir. Olumsuz elektronik ağızdan ağıza pazarlama sadece şikayet ile sınırlı değildir. Tüketicilerin büyük bir kısmı, sosyal medyayı kullanarak (\%80) markaların müşteri hizmetleriyle iletişime geçmekte ve bunların bir kısmı (\%20) şikayet etmektedir (Morrison, 2016). Bu nedenle, yalnızca şikayet davranışından ziyade olumsuz elektronik ağızdan ağıza pazarlama, markaların şikayetlerden daha fazlasını aktif olarak izlemesini sağlayan ve müşteri bağlılığının genel bir göstergesidir (Van Doorn vd., 2010, 254). 


\subsection{Kuşak Kavramı ve Z Kuşağı}

Yıllar boyunca meydana gelen savaşlar, keşifler, siyaset, inanç ve popüler kültür gibi farklı bir dizi olaylar kuşakları tanımlamaya ve sınıflandırmaya yardımcı olmuştur (Meier ve Crocker, 2010, 68). İnsanlık tarihinin başlangıcından günümüze kadar olan süreçte, yaklaşık olarak aynı yıllarda doğmuş, aynı çağın şartlarını, sıkıntılarını paylaşmış, benzer sorumluluklarla yükümlü olmuş kişiler topluluğuna kuşak (jenerasyon) denilmektedir (Kaplan ve Çarıkçı, 2018, 4). Türk Dil Kurumuna göre kuşak; "Hemen hemen aynı senelerde doğmuş, aynı çağın koşullarını ve dolayısıyla aynı sıkıntılara yaşamış, birbirine benzer kaderleri paylaşmış, benzer ödevlerle yükümlü olmuş kişilerin topluluğu" anlamına gelmektedir (www.tdk.gov.tr, 28.05.2017). Genel kabul görmüş kuşak türleri ise; Sessiz Kuşak, Bebek Patlaması (Baby Boomers), X kuşağı, Y kuşağı ve Z kuşağı şeklindedir. Oblinger ve Oblinger (2005)' e göre;

- Sessiz kuşak; 1946 ve öncesi

- Bebek Patlamasi; 1947 - 1964

- X kuşă̆ı; $1965-1980$

- Y kuşağı; 1981 - 1994

- Z kuşağı; 1995 ve sonrası yıllarda doğan kişileri kapsamaktadır.

Her kuşağın kendine özgü birtakım özellikleri, değerleri, algıları, düşünceleri, bakış açıları, yargıları, tutum ve davranışları, zayıf ve güçlü yanları bulunmaktadır (Adıgüzel vd., 2014, 171). Bu çalışmanın da örneklemini oluşturan Z kuşağında yer alan kişiler, çocukluk ve ilk gençlik dönemlerinde; küresel ekonomik kriz, terör olayları ve çevre problemleri gibi olumsuz birtakım olaylara şahit olmuşlardır ve bu durumlardan doğrudan ya da dolaylı olarak etkilenmişlerdir. Olumsuz gelişmelerin yanı sıra, dijital teknolojilerin ve elektronik cihazların gelişmesi ve yaygın kullanılması gibi gelişmelere de tanık olmuşlardır (Sönmez, 2016, 108). Ekonomik, sosyal, kültürel ve teknolojik değişimler sonucunda $\mathrm{Z}$ kuşağı üyeleri, tüketim kararları ve davranışlarında yaşlarının çok ilerisinde etkilerde bulunmaktadırlar. $\mathrm{Bu}$ yüzden, diğer kuşakların oluşturmuş olduğu pazarlama ve tüketim davranışlarını büyük oranda değiştirip geleceğin tüketici profilini biçimlendirecekleri tahmin edilmektedir (Altuntuğ, 2012, 206).

\section{Araştırma Yöntemi}

\subsection{Araştırmanın Amacı ve Önemi}

Olumsuz elektronik ağızdan ağıza pazarlamaya etki eden faktörler, hem potansiyel müşterilerin satın alma karar süreçlerinde hem de işletmelerin faaliyetlerini sürdürmelerinde önemli bir yere sahiptir. Olumsuz elektronik ağızdan ağıza pazarlama ile müşteriler satın alma niyetindeki bir ürünü ya da hizmeti almaktan vazgeçebilecekleri gibi işletmeler de ürettikleri ürünü bu olumsuz paylaşımlardan dolayı satamama sorununu yaşayabilmektedirler. Genel olarak, olumsuz elektronik ağızdan ağıza pazarlama, modern tüketicilerin çevrimiçi ürün veya hizmetlerden memnuniyetsizliklerini ifade ederken tercih ettikleri hızlı ve önemli yollardan biri iken, pozitif elektronik ağızdan ağıza pazarlama konusunda diğer kullanıcıları (müşterileri) da farklı şekilde etkileyebilmektedir. Bu çalışmada olumsuz elektronik ağızdan ağıza pazarlama iletişimine etki eden faktörler ile ilgili Z kuşağı tüketicilerinin görüşlerini belirlemesi amaçlanmıştır. Oblinger ve Oblinger (2005) ile Törocsik vd., (2014)'nin ortak görüşüne göre, Z kuşağında yer alan kişiler 1995 yılı ve üzeri doğumlu olanları kapsamaktadır. Z kuşağı tüketicileri doğum yılları itibariyle değerlendirildiklerinde yaşadıkları ortamın büyük etkisiyle daha teknolojik bir alt yapıya sahiptirler. Bu yüzden diğer kuşakların oluşturmuş olduğu pazarlama ve tüketim davranışlarını büyük oranda değiştirip geleceğin tüketici profilini biçimlendirecekleri tahmin edilmektedir. Dolayısıyla bu kuşak, pazarlamacıların gözde kuşakları arasında yer almaktadır.

\subsection{Araştırmanın Modeli, Evreni ve Örneklemi}

Tanımlayıcı bir araştırma olarak tasarlanan bu çalışmada, olumsuz ağızdan ağıza pazarlamaya etki eden boyutlardan Teknolojik Beceri, Akran Etkisi, Aile etkisi ve Sosyal Medya boyutlarının ifadeleri Zhang vd., (2015)'nin çalışmasından alınırken, Elektronik Posta İletişimi Tercihi, Kendine Güven, Olumsuz Elektronik Ağızdan Ağıza Pazarlama ve Elektronik Ağızdan Ağıza Pazarlama Deneyimi ölçeklerinde yer alan ifadeler ise Boo ve Kim (2013)'den alınmıştır. Araştırmanın evreni Mersin'deki bir vakıf üniversitesinin 2016-2017 akademik yılında kayıtlı olan ve 1995 ve üstü doğumlu olan (2076 kişi) öğrencilerdir. Kolayda örnekleme yöntemiyle belirlenen 330 kişiden anket formu aracılığıyla veriler toplanmıştır. Beşli Likert ölçeğinde hazırlanan anket formunun öncelikle 20 kişi ile ön testi yapılarak gerekli düzeltmelerle anket formu son halini almıştır. Toplanan 330 anket formundan eksik bilgi bulanan ve geçersiz sayılan anketler çıkarılarak toplamda 318 anket formu ile veri analizler gerçekleştirilmiştir.

\section{Analiz ve Bulgular}

SPSS 20 paket programı aracıllğıyla gerçekleştirilen verilerin analizinde tanımlayıcı istatistiki analizler, geçerlilik ve güvenilirlik analizleri ve çoklu doğrusal regresyon analizlerinden yararlanılmıştır. Analiz sonucu demografik ve tanımlayıcı özellikler incelendiğinde; örneklemi oluşturan, bir vakıf üniversitesinde 2016-2017 akademik yılında eğitim gören Z kuşağı öğrencilerinin çoğunluk olarak \%59'unun kadın, \%38'inin 1998 doğumlu olduğu ve diğer bölümlere 
Biztatar, H,. Yaşa Özeltürkay, E., Yalçıntaş, D. / Journal of Yasar University, 2019, 14 (Special Issue), 115-123

kıyasla çoğunluğunun (\%38) İktisadi ve İdari Bilimler Fakültesi'nde eğitim aldığı ve \%15'inin aylık hane gelir düzeylerinin 4500-6000 TL olduğu görülmüştür.

\subsection{Güvenilirlik ve Geçerlilik Analizleri}

SPSS 20 paket programı aracılığıyla veriler güvenilirlik ve geçerlilik analizine tabi tutulmuştur. Faktörler arasında tutarlılık olup olmadığını belirlemek amacıyla Cronbach's Alfa (CA) katsayısı esas alınarak güvenilirlik analizleri yapılmıştır. Tanımlayıcı araştırmalarda bazı araştırmacılara (Kalaycı, 2009; İslamoğlu ve Alnıaçık, 2016) göre güvenilirlik katsayısı 0,60'dan büyük ise ölçek oldukça güvenilir olarak kabul edilirken, bazı araştırmacılar (Gürbüz ve Şahin, 2016; Kurtuluş, 2010) ise 0,70’den büyük alfa değerini uygun görmektedir. Bu çalışmada 0,60 üstü değer güvenilir kabul edilmiştir. Genel ölçekte yer alan 30 ifadenin CA değeri 0.89'dır. Ancak “Kendine Güven” boyutunun güvenilirliği $(0,58)$ düşük çıktığı için modelden çıkarılmıştır. Güvenilirlik analizinden sonra ölçeklerin yapısal geçerliliği test etmek amacıyla faktör analizi yapılmıştır (Tablo 1).

Tablo 1. Faktör Analizi Sonuçları

\begin{tabular}{|c|c|}
\hline FAKTÖRLER & $\begin{array}{l}\text { Faktör } \\
\text { Yükü }\end{array}$ \\
\hline \multicolumn{2}{|l|}{$\begin{array}{l}\text { Faktör 1: Teknolojik Beceri ve Sosyal Medya (TESO) } \\
\text { Özdeğer: 6,652 Açılanan Varyans(\%): 26,610 Cronbach Alpha: ,91 }\end{array}$} \\
\hline SM1: Sosyal ağ sitelerini çok sık ziyaret ederim. & ,590 \\
\hline SM3: Sosyal ağ siteleri aracılığıyla başkalarıyla etkileşim içinde olmayı ve iletişim kurmayı severim. & ,512 \\
\hline TB5: Dizüstü bilgisayarlar, akılı telefon, iPad, AndroidPad gibi mobil aygıtlarını sık sık kullanırım. & ,723 \\
\hline TB6: Mobil aygitları kullanma konusunda kendimi iyi sayarım. & ,708 \\
\hline SM2: Sosyal ağ sitelerini genellikle kullanırım. & ,743 \\
\hline TB4: Kendimi mobil uygulamaları sık kullanan biri olarak görürüm. & ,811 \\
\hline TB2: Mobil uygulamaları sıklıkla kullanırım. & ,784 \\
\hline TB1: Ak1llı telefon, iPad, AndoridPad gibi dijital araçları kullanma konusunda kendime güvenirim. & ,783 \\
\hline TB7: Kendimi mobil araçları sık sık kullanan biri olarak görürüm. & ,798 \\
\hline TB3: Mobil uygulamaları kullanma konusunda kendime güvenirim. & ,753 \\
\hline \multicolumn{2}{|l|}{$\begin{array}{l}\text { Faktör2: Akran ve Aile Etkisi (AILLEAKRANETK) } \\
\text { Özdeğer: } 3,036 \text { Açılanan Varyans(\%): 12,143 Cronbach Alpha: ,83 }\end{array}$} \\
\hline $\begin{array}{l}\text { AKE1:Alışveriş konusunda karar vermeme yardım etmeleri için genellikle arkadaşlarımın/ akranlarımın } \\
\text { fikrini sorarım. }\end{array}$ & 615 \\
\hline AE1: Alışveriş yaparken karar vermemde yardımcı olmaları için genelde ailemin fikrini sorarım. & ,749 \\
\hline AKE3: Karar verme sürecinde arkadaşlarım / akranlarım beni çok etkiler. & ,737 \\
\hline AE3: Karar alma sürecimde ailem beni çok etkiler. & ,786 \\
\hline AKE4: Arkadaşlarımın / akranlarımın seçimlerine - tercihlerine katılırım. & 617 \\
\hline AKE2: Arkadaşlarımın / akranlarımın fikrine çok önem veririm. & ,717 \\
\hline AE4: Ailemin doğru olduğunu düşündüğü şeyleri daha çok yaparım. & ,513 \\
\hline \multicolumn{2}{|l|}{$\begin{array}{l}\text { Faktör 3: Elektronik Ağızdan Ağıza Pazarlama Deneyimi (EDEN) } \\
\text { Özdeğer: } 2,183 \text { Açılanan Varyans(\%): 8,730 Cronbach Alpha: ,69 }\end{array}$} \\
\hline ED3: İnternette tartışma forumlarına katılmayı severim. & ,695 \\
\hline ED1:Tüketici görüşlerinin belirtildiği bir site veya blog üzerinden fikrimi genellikle belirtirim. & ,778 \\
\hline ED2: Genellikle e-posta aracılığıyla şikayette bulunurum. & ,658 \\
\hline \multicolumn{2}{|l|}{$\begin{array}{l}\text { Faktör 4: Olumsuz Elektronik Ağızdan A ̆̆ıza Pazarlama (EAAP) } \\
\text { Özdeğer: 1,647 Açıklanan Varyans(\%): 6,589 Cronbach Alpha: ,74 }\end{array}$} \\
\hline $\begin{array}{l}\text { EA1: Sosyal ağ siteleri ve mobil teknoloji aracılığıyla kötü hizmet sunan bu restoranın bilgilerini çevrimiçi } \\
\text { (online) olarak paylaşırım. }\end{array}$ & ,564 \\
\hline $\begin{array}{l}\text { EA2: Sosyal ağ siteleri ve mobil teknoloji üzerinden olumsuz hizmet deneyimimle ilgili yaşadı̆̆ım hayal } \\
\text { kırıklığımı arkadaşlarımla paylaşırım. }\end{array}$ & ,838 \\
\hline $\begin{array}{l}\text { EA3: Sosyal ağ ve mobil teknoloji aracılığıyla kötü hizmet sunan bu kurumun bilgilerini arkadaşlarıma } \\
\text { iletirim. }\end{array}$ & 829 \\
\hline \multicolumn{2}{|l|}{$\begin{array}{l}\text { Faktör 5: Elektronik Posta Iletişimini Tercih (EPOST) } \\
\text { Özdeğer: } 1,297 \text { Açılklanan Varyans(\%): 5,187 Cronbach Alpha: ,64 }\end{array}$} \\
\hline EP1:Daha çok şirketin e-mail yoluyla müşteri şikayetlerini ele alması gerektiğini düşünüyorum. & ,777 \\
\hline EP2: E-mail şirketlerin müşterilerle iletişim kurması için iyi bir yoldur. & 805 \\
\hline
\end{tabular}


Biztatar, H,. Yaşa Özeltürkay, E., Yalçıntaş, D. / Journal of Yasar University, 2019, 14 (Special Issue), 115-123

(*) Varimax Rotasyonlu Temel Bileşenler Analizi, Özdeğer> 1, Kaiser-Meyer-Olkin (KMO) Testi: 0,85, Bartlett Testi, Yaklaşık Ki-Kare değeri: 3135,930, Sig.: 0.00, p<0,05, Faktör Yükleri > 0,50, Açıklanan Toplam Varyans: \%59,259.

Örneklemin faktör analizi için yeterliliğini ölçmek için Kaiser-Meyer-Olkin $(\mathrm{KMO}=, 85)$ değeri ile Barlett küresellik test $(\mathrm{p}<0,05 ; \mathrm{p}=0.000)$ değerlerine bakılmıştır. Bu değerlere gore örneklem yeterli olarak kabul edilmektedir (Nakip, 2013, 518; İslamoğlu ve Alnıaçık, 2016, 416). Ilk ölçekte ayrı olarak yer alan Teknolojik Beceri ve Sosyal Medya boyutları tek bir boyut olarak birleşmiştir. Benzer şekilde Aile Etkisi ve Akran Etkisi boyutları da tek bir faktöre dönüşmüştür. Ayrıca üç ifadeyle ölçülen Kendine Güven boyutunun CA değeri kabul edilen aralıktan düşük çıtığı $(0,58)$ için bu boyut ölçekten çıkarılmıştır. Ölçekte yer alan iki ifade (AE2 ve EP3) ise 0,50 faktör yükünün altında bir değer aldığ1 için ölçekten çıkarılmıştır. Faktör analizi sonucunda toplam varyansın \%59,25’1 açıklanmış olup bu değer sosyal bilimlerde yeterli olarak kabul edilmektedir (Südaş, 2012, 15). Böylelikle faktör analizi sonrasında 30 ifade 25 ifadeye indirgenerek beş boyut altında toplanmıştır. Araştırmada analizler sonrası revize edilen ve geliştirilen araştırma modeli Şekil 1'dedir.

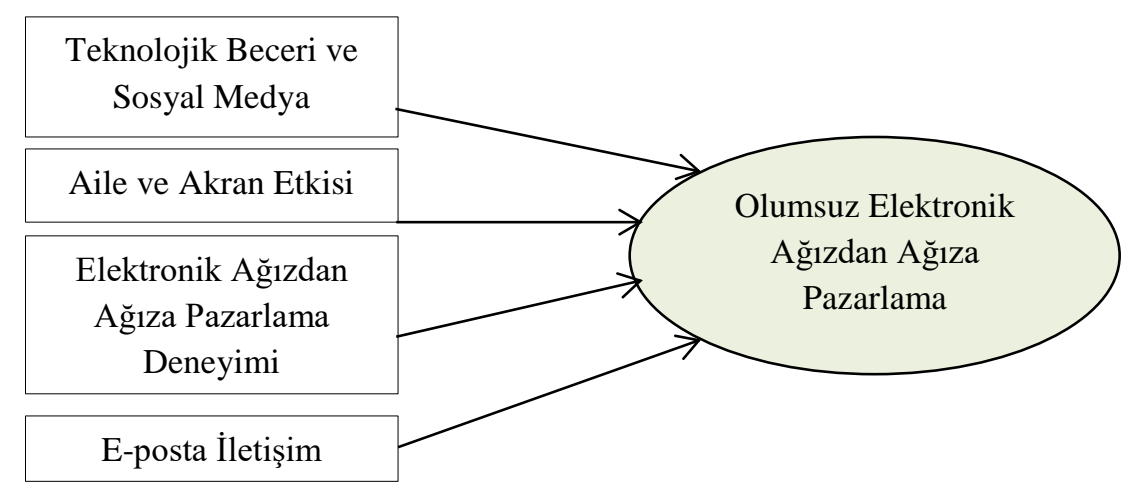

Şekil 1. Revize Edilmiş Araştırma Modeli

Zhang vd., (2015) Boo ve Kim (2013)'in çalışmalarına dayanarak oluşturulan ana araştırma modeli, geçerlilik ve güvenilirlik analizleri sonrasında Şekil 1'deki halini almış olup, revize edilmiş araştırma modeli doğrultusunda oluşturulan hipotezler şu şekildedir:

H1: Aktif sosyal medya kullanıcısı olan ve teknolojik beceriye sahip Z kuşağı tüketicileri olumsuz bir deneyim yaşadıktan sonra olumsuz elektronik ağızdan ağıza pazarlama yapma eğilimindedirler.

H2: Aile ve akranlarından etkilenen $\mathrm{Z}$ kuşağı tüketicileri olumsuz elektronik ağızdan ağıza pazarlama yapma eğilimindedirler.

H3: Daha önceden elektronik ağızdan ağıza pazarlama deneyimine sahip olan ve memnun olmamış $Z$ kuşağı tüketicileri, daha fazla olumsuz elektronik ağızdan ağıza pazarlama yapma niyetindedirler.

H4: Elektronik posta aracılığıyla iletişimi tercih eden memnun olmamış Z kuşağı tüketicileri, daha fazla olumsuz elektronik ă̆ızdan ağıza pazarlama yapma eğilimindedirler.

\subsection{Hipotez Testleri}

Hipotezlerin test edilmesinde SPSS programı üzerinden regresyon analizi uygunlanmıştır. Regresyon analizi, iki değişken arasında ilişkinin olduğu ve değişkenlerin biri üzerinde yapılan değişikliklerin (bağımsız değişken) diğeri üzerinde (bağımlı değişken) değişim yarattığı durumlarda kullanılarak bu etkinin tanımlanmasını amaçlamaktadır (Kurtuluş, 2010, 186). Bir bağımlı değişken ile birden fazla bağımsız değişkenin arasındaki ilişkinin aranması çoklu regresyon analizi ile sağlanır (Nakip, 2013, 413). Yapılan bu çalışmada bir bağımlı ve birden fazla bağımsız değişken olması sebebiyle çoklu regresyon analizi yapılmış olup analiz sonuçları Tablo 2'de gösterilmektedir.

Tablo 2. Regresyon Analizi Sonuçları

\begin{tabular}{|c|c|c|c|c|c|c|c|c|}
\hline \multirow[t]{2}{*}{ Model } & \multicolumn{2}{|c|}{$\begin{array}{c}\text { Standartlaşmamış } \\
\text { Katsayı }\end{array}$} & \multirow{2}{*}{$\begin{array}{c}\text { Standart } \\
\text { Katsayı } \\
\text { Beta }\end{array}$} & \multirow{2}{*}{$\mathrm{t}$} & \multirow{2}{*}{$\begin{array}{l}\text { Sig. } \\
\text { (p) }\end{array}$} & \multicolumn{2}{|c|}{ Doğrusallık İstatistikleri } & \multirow[t]{2}{*}{$\begin{array}{l}\text { Durbin- } \\
\text { Watson }\end{array}$} \\
\hline & B & Std. Hata & & & & Tolerans & VIF & \\
\hline (sabit terim) & 1,473 & ,338 & & 4,354 & & & & 1,919 \\
\hline EPOST & ,230 &, 058 &, 215 & 3,959 & ,004 & ,893 & 1,120 & \\
\hline AİLEAKRANETK & ,013 & ,067 & ,011 & ,198 & 843 & ,889 & 1,125 & \\
\hline TESO & ,204 & ,070 & , 158 & 2,898 & ,000 & ,884 & 1,131 & \\
\hline EDEN & ,210 & ,049 & 234 & 4,299 & ,000 & ,892 & 1,120 & \\
\hline
\end{tabular}


Biztatar, H,. Yaşa Özeltürkay, E., Yalçıntaş, D. / Journal of Yasar University, 2019, 14 (Special Issue), 115-123

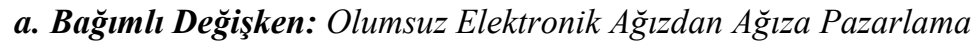

b.Bă̆ımsız Değişkenler: Elektronik Posta İletişimi Tercihi (EPOST), Aile ve Akran Etkisi (AILLEAKRANETK), Teknolojik Beceri ve Sosyal Medya (TESO), Elektronik Ă̆ızdan A

$F=17,541, p<0,001, R^{2}=0,186$, Düzeltilmiş $R^{2}=, 175$

Elde edilen bulgulara göre “Aile ve Akran Etkisi” değişkeninin olumsuz elektronik ağızdan ağıza pazarlamayla ilişkisinde $\mathrm{p}>0,05$ olduğundan istatistiksel olarak anlamlı bir ilişki bulunamamıştır. Dolayısıly $\mathrm{H}_{2}$ desteklenmemiştir. $\mathrm{Z}$ kuşağ1 tüketicilerinin elektronik posta iletişimi tercihleri $(\beta=, 215 ; \mathrm{p}<0,05)$, teknolojik beceri ve sosyal medya $(\beta=, 158$; $\mathrm{p}<0,05)$ ve elektronik ağızdan ağıza pazarlama deneyimi $(\beta=, 234 ; p<0,05)$ boyutları olumsuz elektronik ağızdan ağıza pazarlamayı etkilemektedir. Dolayısıyla $\mathrm{H}_{1}, \mathrm{H}_{3}$ ve $\mathrm{H}_{4}$ hipotezleri desteklenmiştir. Modelde $\mathrm{R}^{2}$ değerine bakıldığında olumsuz elektronik ağızdan ağıza pazarlamanın \%18'inin bağımsız değişkenler tarafından açıklandığını göstermektedir. Çoklu eş doğrusallık değerleri incelendiğinde ise eğer Tolerans değeri kritik değerden $\left(1-\mathrm{R}^{2}\right)$ küçükse çoklu eş doğrusallık sorununun olduğunu gösterir (Gürbüz ve Şahin, 2016, 279). Kritik değer, 1-0,186=0,814'tür. Tablodaki Tolerans değerlerine bakıldığında değerlerin tümünün kritik 0,814'ten büyük olduğu görülmüştür. Dolayısıyla çoklu eş doğrusallık sorunu yoktur. Variance Inflation Factor (VIF) değerinin 2'den büyük olması genellikle sorunlu bir durum olduğunu gösterir (İslamoğlu ve Alnıçık, 2016, 379). Tabloda yer alan VIF değerlerinin hepsinin 2'den düşük olması problemli bir durumun olmadığını göstermiştir. Modelde yer alan Durbin-Watson değeri ise 1,5-2,5 arasında ise modele dâhil edilen bağımsız değişkenlerin arasında otokorelasyon olmadığını göstermektedir (Boymul ve Yaşa Özeltürkay, 2017, 99). Bu değerin 1,919 olması anlamlı olduğunu göstermektedir.

\section{Tartışma ve Sonuç}

Hızla gelişen ve değişen teknolojiyle birlikte özellikle internetin yaygınlaşmasıyla tüketiciler satın alma süreçlerinin her aşamasında ağızdan ağıza pazarlama faaliyetlerini aktif bir şekilde kullanmaktadır. Böylelikle tüketiciler satın alma süreçlerinde edindikleri olumlu ve olumsuz deneyimleri her ortamda bilinçli veya bilinçsiz bir şekilde dile getirebilmektedirler. Tüketicilerin bu davranışı diğer kişilerin de satın alma kararlarını, ürün veya hizmet ile ilgili düşüncelerini etkilemektedir. Nitekim pek çok tüketici reklamlardan ve tanıtımlardan daha çok, yakın çevrelerinde bulunan insanların ürün ya da hizmet ile ilgili düşüncelerine önem vermektedir. Ve insanlar hayal kırıklığına uğrağında, ürün/hizmetten beklediği deneyimi elde edemediğinde genellikle olumsuz ağızdan ağıza pazarlamaya yönelebilirler. Teknolojide gerçekleşen gelişmeler ile birlikte hayatımıza giren önemli bir unsur olan sosyal medya, özellikle Z kuşağ 1 üyelerinin günlük yaşamının vazgeçilmez bir parçası haline gelmiştir. Bunun nedeni ise, Z kuşağı üyelerinin doğdukları andan itibaren dijital teknolojilerin (internet, sosyal medya vb.) ve elektronik cihazların (bilgisayar, cep telefonu, tablet vb.) gelişmesine tanık olmalarıdır.

Bu çalışmada Boo ve Kim (2013) ve Zhang vd. (2015)'nin çalışmaları derlenerek, beşli Likert ölçeği ile oluşturulan 30 ifadeli bir ölçek aracılığıyla Z kuşağı tüketicilerinin olumsuz elektronik ağızdan ağıza pazarlama iletişimine etki eden faktörlerin belirlemesi amaçlanmıştır. Çalışma kapsamında görüşleri alınan Z kuşağı bireylerinin teknolojiyi ve sosyal medyayı kullanma becerileri, elekronik posta aracılığı ile iletişim kurabilmeleri (şikayette bulunabilme), çevrimiçi platformlarda görüş ve şikayetlerini kolaylıkla dile getirmeleri gibi faktörlerin olumsuz ağızdan ağıza pazarlama davranışını etkilediği ortaya konmuştur. Ayrıca, katılımcıların çoğunluğunun aile ve akranlarından etkilenmeden olumsuz elektronik ağızdan ağıza pazarlama yaptıkları sonucuna ulaşılmıştır. Benzer çalışmalarla (Drennan ve McColl-Kennedy, 2003; Mattila ve Mount, 2003; Cheung vd., 2008; Vermeulen ve Seegers, 2009; Boo ve Kim, 2013; Zhang vd., 2015; Luo vd., 2018; Philp vd., 2018; Weitzl vd., 2018; Chung ve Lee, 2019) karşılaştırıldığında da genel olarak çevrimiçi platformlarda yer alan olumsuz durum ve yorumların tüketici davranışlarını, tutum ve niyetlerini etkiledikleri söylenebilir. Nitekim; Drennan ve McColl-Kennedy (2003), internetin, müşterilere ulaşmak için e-posta kullanımı ve müşteri geri bildirimi gibi belirli işlevlerinin, küçük perakende şirketleri için firma performansıyla pozitif ilişkili olduğunu ortaya koyarak; firma performansının, müşterilerin memnuniyet düzeyini etkilediğini ve onların elektronik ağızdan ağıza pazarlama faaliyetlerine katılımlarını sağladığını ifade etmiştir. Mattila ve Mount (2003), memnun olmayan müşterilerin kötü deneyimlerini internet şikayetleriyle veya inceleme siteleri aracılığıyla çok sayıda başka müşteriyle anında paylaşabildiklerini belirterek olumsuz elektronik ağızdan ağıza pazarlamanın bir otel şirketinin itibarına kartopu etkisi yapabileceğini ifade etmiştir. Cheung vd. (2008) çalışmasında, restoranlar hakkındaki bilgilerin kullanışlılığının, bir müşterinin çevrimiçi topluluklar tarafından sağlanan bilgileri kabul etme kararını etkilediğini ortaya koymuştur. Müşterilerin elektronik ağızdan ağıza pazarlamalarının daha fazla bilginin benimsenmesine yol açtığını ve bu sayede bir restoranı ziyaret eden daha fazla müşteriye yol açtığını belirtmiştir. Vermeulen ve Seegers (2009) ise çevrimiçi otel incelemelerinin etkisine ilişkin deneysel çalışmalarında, otellerde çevrimiçi incelemelere maruz kalmanın tüketici bilincini önemli ölçüde artırdığını ortaya koymuşlardır. Boo ve Kim (2013)'in çalışmasında da elektronik ağızdan ağıza pazarlama deneyiminin ve elektronik posta iletişimi tercihinin olumsuz ağızdan ağıza pazarlamaya etkisi olduğu belirlenmiştir. Zhang vd. (2015)'nin Y kuşağı üzerinde uygulamış oldukları çalışmada sosyal medya ve teknolojik beceri ile aile etkisi ve akran etkisi ayrı boyutlar altında olup olumsuz elektronik ağızdan ağıza pazarlama üzerinde etkiye sahiptir. Luo vd. (2018), olumsuz çevrimiçi ağızdan iletişimcinin alıcı ile olan ilişkisinde, tüketicinin ürüne ilgisi ve güven eğilimlerinin satın alma niyetini etkilediğini; miktar, kalite ve olumsuz çevrimiçi ağızdan ağıza bilgi yoğunluğunun ise alıcıların ağızdan ağıza duyduğu güvenini olumlu yönde etkileyerek satın alma niyetlerini daha da etkilediği sonucuna 
ulaşmıştır. Philp vd. (2018) ise tüketicilerin kendini sevme ve kendi kendine yeterlilik boyutları açısından yaptıkları incelemede bu boyutların olumsuz ağızdan ağıza paylaşım üzerinde ters etki yaratacağını öne sürmüştür. Ayrıca kendi kendine yeterliliği yüksek olan kişilerin, ağızdan ağıza paylaşım konusunda daha az istekli olduklarını ortaya koymuşlardır. Weitzl vd. (2018) çevrimiçi bir şikayete yanıt olarak gönderilen mesajların şikayetçilerin başarısızlık nitelikleri ve ağızdan ağıza sözleri nasıl hafiflettiği üzerine deneysel olarak gerçekleştirdikleri çalışmalarında bu yanıt mesajlarının şikayetçilerin olumsuz başarısızlık niteliklerini (konum, kontrol edilebilirlik ve kararlılık) azaltabileceğini savunmuşlardır. Chung ve Lee (2019) ise çalışmasında kurumsal sosyal sorumluluk ile olumsuz ağızdan ağıza pazarlama ilișkisini araştırmıștır. Sonuç olarak kurumsal sosyal sorumluluğun satın alma niyetini olumlu yönde etkileyeceğini, dolayısıyla tüketicilerin şirkete karşı tutumlarını pozitif yönde etkileyerek olumsuz ağızdan ağıza pazarlamayı negatif yönde etkileyeceğini belirtmişlerdir. Benzer çalışmalardaki sonuçlar karşılaştırıldığında bazı farklılıkların olduğu gözlemlenmiştir. Ölçeklerin farklı kültürlerde gerçekleştirilmesi sonucunda ölçeklerin farklı faktörler altında toplanması ve farklı sonuçlar çıkabilmesi önceki çalışmalarda da rastlanabilen bir durumdur.

Z kuşağındaki sosyal medyayı ve mobil uygulamaları aktif kullanan ve alışverişte karar alma sürecinde aile ve akranlarından etkilenmeyen bu grup için işletmeler, bu kuşağın sıklıkla kullandıkları sosyal ağları ve mobil uygulamaları daha yakından takip ederek olumsuz görüşlerini bildiren Z kuşağı tüketicileriyle etkileşimde bulunup sorunu en k1sa sürede gidermeleri önerilebilir. Z kuşağındaki bu grup içinde elektronik ağızdan ağıza pazarlama deneyiminin olumsuz elektronik ağızdan ağıza pazarlama üzerinde etkisi olduğu görülmüştür. Elektronik ağızdan ağıza pazarlama deneyimine önem veren bu grup için işletmeler, forum ve şikayet sitelerindeki görüşleri dikkate alarak tüketiciye hemen geri dönüş yapmaları önerilebilir. Z kuşağı genelde sosyal medya araçları üzerinden şikayetlerini dile getirirken aynı zamanda epostayla da şikayet etmeyi tercih edebilirler. Bu açıdan işletmelerin müşteri şikayetlerinin ele alması ve müşterilerle eposta üzerinden iletişim kurması Z kuşağındaki bu grup için uygun ve etkili olabilir. Araştırmanın sonuçlarına dayanarak çalışmanın sadece bir gruba uygulanması nedeniyle sonuçlar ve öneriler genellenemez. 
Biztatar, H,. Yaşa Özeltürkay, E., Yalçıntaş, D. / Journal of Yasar University, 2019, 14 (Special Issue), 115-123

\section{KAYNAKÇA}

Adıgüzel, O., Batur, H. Z. ve Ekşili, N. (2014). “Kuşakların değişen yüzü ve Y kuşağı ile ortaya çıkan yeni çalışma tarzı: Mobil yakalılar", Süleyman Demirel Üniversitesi Sosyal Bilimler Enstitüsü Dergisi, (19):165-182.

Arndt, Johan. (1967). "Role of product-related conversations in the diffusion of a new product", Journal of marketing Research, 4(3):291-295.

Altuntuğ, Nevriye. (2012). “Kuşaktan kuşağa tüketim olgusu ve geleceğin tüketici profili”, Organizasyon ve Yönetim Bilimleri Dergisi, 4(1):203-212.

Boo, S. ve Kim, J. (2013). "Comparison of negative eWOM intention: An exploratory study", Journal of Quality Assurance in Hospitality \& Tourism, 14(1):24-48.

Boymul, E. ve Yaşa Özeltürkay, E. (2017). “İş tatmini ve örgütsel bağlılığın tükenmişlik sendromu üzerindeki etkisi: Bir sanayii kuruluşunda uygulama", Journal of Yasar University, 12(46):93-102.

Brown, J., Broderick, A. J., ve Lee, N. (2007). "Word of mouth communication within online communities: Conceptualizing the online social network", Journal of Interactive Marketing, 21(3):2-20.

Buttle, Francis A. (1998). "Word of mouth: Understanding and managing referral marketing", Journal of Strategic Marketing, (6):241-254.

Chen, Yi-fan. (2015). Managing negative eWOM by response from the perspective of luxury hotel managers, PhD Thesis School of Hotel And Tourism Management, The Hong Kong Polytechnic University, Hong Kong.

Cheung, C. M. K., Lee, M. K. O., ve Rabjohn, N. (2008). “The impact of electronic word-of-mouth”, Internet Research, 18(3):229-247.

Chung, A., ve Lee, K. B. (2019). "Corporate apology after bad publicity: A dual-process model of CSR fit and CSR history on purchase intention and negative word of mouth. International Journal of Business Communication, 121.

Desatnick, Robert L. (1987). The Jossey-Bass management series. Managing to keep the customer: How to achieve and maintain superior customer service throughout the organization. San Francisco, CA, US: Jossey-Bass, https://psycnet.apa.org/record/1987-97297-000, Erişim Tarihi: 22.07.2019.

Drennan, J., ve McColl-Kennedy, J. (2003). “The relationship between Internet use and perceived performance in retail and professional service firms", Journal of Services Marketing, 17(3):295-311.

Göktaş, B., ve Tarakçı, İ. E. (2018). “Ağızdan ağıza pazarlamanın pazarlama araçları içerisindeki önemi ve satın alma davranışlarını şekillendirmesine yönelik bir uygulama”, Third Sector Social Economic Review, 53(3), 1019-1033.

Gürbüz, S. ve Şahin F. (2016). Sosyal Bilimlerde Araştırma Yöntemleri, Felsefe-Yöntem-Analiz, Seçkin Yayıncılık, İstanbul.

Güven, Esra. (2014). Sosyal medyadaki ağızdan ağıza pazarlama faaliyetlerinin satın alma kararları üzerine etkileri, Doktora Tezi, Celal Bayar Üniversitesi Sosyal Bilimler Enstitüsü, Manisa.

Eckleberry-Hunt, J. ve Tucciarone, J. (2011). "The challenges and opportunities of teaching 'Generation Y"”, Journal of Graduate Medical Education, 3(4):458-461.

Ezzatırad, Haleh. (2014). Ağızdan ağıza pazarlamanın müşteri satın alma karar sürecine etkisi: Ankara'daki devlet üniversitelerinin iktisadi ve idari bilimler fakülteleri öğrencileri arasında bir uygulama, Yayınlanmamış Yüksek Lisans Tezi, Gazi Üniversitesi Sosyal Bilimler Enstitüsü, Ankara.

İslamoğlu, A., H. ve Alnıaçı, Ü. (2016), Sosyal Bilimlerde Araştırma Yöntemleri. İstanbul: Beta Yayınları.

Kalaycı, Şeref. (2009). SPSS Uygulamalı Çok Değişkenli İstatistik Teknikleri. Ankara: Asil Yayın Dağıtım.

Kamiloğlu, F., Yurttaş, U. Ö. (2014). "Sosyal medyanın bilgi edinme ve kişisel gelişim sürecine katkısı ve lise öğrencileri üzerine bir alan çalışması", İletişim (21):130-150.

Kaplan, B. T., ve Çarıkçı, İ. H. (2018). "İş dünyasında jenerasyonlar: X, Y ve Z jenerasyonları üzerine kavramsal bir inceleme", Balkan ve Yakın Doğu Sosyal Bilimler Dergisi, 4(1): 25-32.

Kurtuluş, Kemal. (2010). Araştırma yöntemleri. İstanbul: Türkmen Kitabevi.

Kwon, J.M., Bae, J. ve Phelan, K. (2011). "Online consumer herding behaviors in the hotel industry", http://scholarworks.umass.edu/gradconf_hospitality/2011/Poster/124, Erişim Tarihi: 22.10.2019.

Lee, M. ve Youn, S. (2009). "Electronic word of mouth", International Journal of Advertising, 28 (3): 479-499.

Lee, W., Tyrrell, T. ve Erdem, M. (2013). "Exploring the behavioral aspects of adopting technology: Meeting planners' use of social network media and the impact of perceived critical mass", Journal of Hospitality and Tourism Technology, 4(1):6-22.

Luo, H., Huang, W., Chen, C., Xie, K., ve Fan, Y. (2018). “An empirical study on the impact of negative online word-ofmouth on consumer's purchase intention", 15th International Conference on Service Systems and Service Management (ICSSSM), 1-6.

Mattila, A. S., ve Mount, D. J. (2003). "The impact of selected customer characteristics and response time on E-complaint satisfaction and return intent”, International Journal of Hospitality Management, 22(2):135-145.

Meier, J., ve Crocker, M. (2010). "Generation Y in the workforce: Managerial challenges", The Journal of Human Resource and Adult Learning, 6(1):68.

Mitchell, V., Petrovici, D., Schlegelmilch, B.B. ve Szőcs, I. 2015. "The influence of parents versus peers on Generation Y Internet ethical attitudes", Electronic Commerce Research and Applications, 14(2):95-103. 
Biztatar, H,. Yaşa Özeltürkay, E., Yalçıntaş, D. / Journal of Yasar University, 2019, 14 (Special Issue), 115-123

Morrison, Kimberlee. (2016). $80 \%$ of consumers use digital devices to contactcustomer service (Report),www.adweek.com/digital/80-of-consumers-use-digital-devices-to-contact-customer-service-report/, Erişim Tarihi: 22.07.2019.

Nakip, Mahir. (2013). Pazarlamada Araştırma Teknikleri ve SPSS Uygulamaları. Ankara: Seçkin Yayıncılık.

Nusair, K., Bilgihan, A. ve Okumus, F. (2013). "The role of online social network travel websites in creating social interaction for Gen Y travelers", International Journal of Tourism Research, 15(5):458-472.

Oblinger, D. G. ve Oblinger, J. L. (2005). Educating the NET Generation, EDUCASE Online Book. http://www.educause.edu/ir/library/pdf/pub7101.pdf , Erişim Tarihi: 13.04.2017.

Okan, E. Y., ve Şahin, A. (2016). "İnternet kullanımı motivasyonlarının elektronik ağızdan ağıza iletişim (e-wom) ile ilişkisi üzerine ampirik bir araştırma”, Global Media Journal: Turkish Edition, 7(13):49-62.

Özkan, E. ve Yıldız, S. (2015). "Müşteri sadakati ile ağızdan ağıza iletişimin tüketici satın alma davranışlarına etkisi: Elektronik eşya sektöründe bir uygulama”, Uluslararası İktisadi ve İdari Íncelemeler Dergisi, 8(15):359-380.

Philp, M., Pyle, M. A., ve Ashworth, L. (2018). "Risking the self: the impact of self-esteem on negative word-of-mouth behavior", Marketing Letters, 29(1):101-113.

Sönmez, Fatih. (2016). Sosyal medyanın, Z kuşağı tüketicilerinin satın alma davranışları üzerindeki etkisi, Yayınlanmamış Yüksek Lisans Tezi, Celal Bayar Üniversitesi, Sosyal Bilimler Enstitüsü, Manisa.

Südaş Doğan, Hatice. (2012). Elektronik ağızdan ağıza iletişim motivlerinin tüketici satın alma ve iletişim davranışlarına etkisi, Doktora Tezi, Çukurova Üniversitesi, Sosyal Bilimler Enstitüsü, Adana.

Toros Dapiapis, N. (2016). "Pazarlama iletişimi açısından internet ortamında kullanılan ağızdan ağza pazarlama tekniklerinin marka tercihine etkisi”, Üsküdar Üniversitesi Sosyal Bilimler Dergisi, 1(1):157-182.

Törőcsik, M., Szücs, K., ve Kehl, D. (2014). "How generations think: Research on generation Z”, Acta Universitatis Sapientiae, Communicatio, 1(1):23-45.

Türk Dil Kurumu, www. tdk.gov.tr, Erişim Tarihi: 28.05.2017.

Uyar, A. ve Kılıçaslan, K. (2016). "Negatif ağızdan ağıza pazarlama: Hazır giyim ve beyaz eşya ürünleri üzerine bir araştırma", Global Business Research Congress (Gbrc), İstanbul.

Van Doorn, J., Lemon, K. N., Mittal, V., Nass, S., Pick, D., Pirner, P., ve Verhoef, P. C. (2010). “Customer engagement behavior: Theoretical foundations and research directions", Journal of Service Research, 13(3):253-266.

Vermeulen, I. E., ve Seegers, D. (2009). "Tried and tested: The impact of online hotel reviews on consumer consideration", Tourism Management, 30(1):123-127.

Vilpponen, A., Winter, S., ve Sundqvist, S. (2006). "Electronic word-of-mouth in online environments: exploring referral network structure and adoption behavior", Journal of Interactive Advertising, 6(2):71-86.

Weitzl, W., Hutzinger, C., ve Einwiller, S. (2018). “An empirical study on how webcare mitigates complainants' failure attributions and negative word-of-mouth", Computers in Human Behavior, 89:316-327.

Yavuzyılmaz, Oğuz. (2015). “Ağızdan ağıza pazarlama”, Akademik Sosyal Araştırmalar Dergisi, 3(14):429-448.

You, Y., Vadakkepatt, G. G., ve Joshi, A. M. (2015). “A meta-analysis of electronic word-of-mouth elasticity”, Journal of Marketing, 79(2):19-39.

Yurdakul, B. Nilay. (2003). Bütünleşik pazarlama iletişiminde ölçümleme süreci, Doktora Tezi, Ege Üniversitesi Sosyal Bilimler Enstitüsü, İzmir.

Zhang, T., C., Omran, B., A., ve Cobanoglu, C. (2015). “Generation Y's positive and negative ewom: Use of social media and mobile technology”, International Journal of Contemporary Hospitality Management, 29(2):732-761. 